\title{
Sowing date as a factor determining French bean yield for processing
}

\author{
Helena Labuda, Anna Brodaczewska \\ Department of Vegetable Crops and Medicinal Plants \\ University of Life Sciences in Lublin \\ Leszczyńskiego 58, 20-068 Lublin, Poland \\ e-mail: helena.labuda@up.lublin.pl
}

\begin{abstract}
Field studies were conducted in the years 2003-2005 in the Experimental Farm of the University of Life Sciences in Lublin. Beans from four cultivars - 'Paulista' and 'Hit' (green pods) and 'Korona' and 'Galopka' (yellow pods) - were grown on fawn soil, formed of loess deposits, on chalky marls, containing 1.4\% organic substances on average. There were six sowing terms, every 6-7 days starting from the middle of May to the end of June. French bean harvest was performed once, when about $75 \%$ of the pods on the plants were in the phase of technological maturity, which fell between the third ten days of July and the first ten days of September. From the plot and plant the number and yield of the pods were determined: total, marketable and non-marketable small pods, unshapely and overripe pods, as well as those with symptoms of disease. The highest total and marketable pod yields - on average, 15.45 and $11.06 \mathrm{t} \mathrm{ha}^{-1}$, respectively - were obtained from plants sown in the first ten days of June, whereas the lowest - 12.54 and $9.54 \mathrm{t} \mathrm{ha}^{-1}$ - were from those sown in the middle of May. As a result of performing a one-time French bean pod harvest, the share of non-marketable pod yield in the total yield was on a similar level (24-28\%), depending on the growing term. Variability was demonstrated in the share of particular non-marketable yield fractions (small pods, undersized, unshapely, and overripe pods, as well as those with disease symptoms), depending on the sowing date. Growing four French bean cultivars from sowing in the period from the middle of May to the end of June allowed us to extend the period of fresh pod harvest to six or seven weeks.
\end{abstract}

Key words: bean, cultivars, environmental factors, Phaseolus vulgaris L., yield structure

\section{INTRODUCTION}

Growing French beans for processing is of crucial importance in Poland. It comprises an area of about 7.5 thousand ha. The production exceeds 52 thousand tonnes, of which most is designed for freezing and canning. The export of frozen French beans in the years 2007-2009 reached 25-28 thousand tonnes (Milczyńska and Lenartowicz 2007, Nosecka et al. 2009, Nosecka and Bugała 2010).

In growing French beans for processing, a long period of delivering material for processing, lasting several weeks, is significant. In addition, there are strict requirements concerning the quality of pods designed for freezing and canning. At present, material for processing is possible from both French bean cultivars with green and yellow pods (Elkner and Nowakowska 2000, Anonymous 2002, Bąkowski 2002). The yielding of French beans and the accessibility of material for processing depend on many factors - the cultivar, sowing date, harvest method and, above all, on environmental conditions (Gross and Kigel 1994, Rolbiecki and Rzekanowski 1996, Mouhouche et al. 1998, Łabuda et al. 2006, Łabuda and Brodaczewska 2007 b). Studies concerning growing French beans for processing, conducted some time ago (Plucińska 
et al. 1977, Kossowski et al. 1978), revealed that the genetic features of cultivars affected the concentration and evenness of pod setting to the greatest extent, as well as yielding structure.

The consumption of fresh French bean pods is on a low level, is of a distinctly seasonal character, and falls mainly in the period of harvest from field growing. What contributes to the increase of French bean pod consumption is growing beans in foil tunnels (Labuda and Brodaczewska 2007 a), and, above all, a broader application of frozen French beans in everyday diets (Górska-Warsewicz 2003).

French bean, as a thermophilous plant with a short vegetation period, can be grown from sowing, starting from the middle of May to the end of June, which, with the selection of several cultivars, allows for an extension of the harvest from about the middle of July to the first ten days of September.

The aim of the present study was to get acquainted with and trace the yielding of French bean grown for processing after sowing on various dates - from the middle of May to the end of June. It was significant to determine the length of the harvest period, the structure of pod yield, considering cultivars with yellow and green pods, as well as to apply a one-time pod harvest in the optimal phase of technological maturity for processing.

\section{MATERIAL AND METHODS}

Field studies were conducted in the years 2003-2005 in the Felin Experimental Farm of the University of
Life Sciences in Lublin. Beans were grown on fawn soil, formed of loess deposits, on chalky marls, containing on average $1.4 \%$ of organic substance. Fertilisation was based on the results of soil analysis (Tab. 1); only the content of mineral nitrogen was supplemented to $30 \mathrm{mg} \mathrm{dm}^{-3}$ of soil (ammonium saltpetre was applied) during the study period.

The experiments were established as two-factor one, using the method of random blocks in four repetitions. The experiment factors were: $\mathrm{A}-$ six sowing terms - in the period from the middle of May, every 6-7 days to the end of June, and B - four French bean cultivars: 'Paulista' and 'Hit' (green pods) and 'Korona' and 'Galopka' (yellow pods) (Tab. 2). The plot surface was $4.05 \mathrm{~m}^{2}$ (length: $3.0 \mathrm{~m}$ and width: $1.35 \mathrm{~m}$ ), with a plant spacing of $0.45 \mathrm{~m} \times 0.08 \mathrm{~m}$. The dressed seeds (Funaben T + Marshal 250 DS) were sown in three rows, two in each point, and stopped after plant germination.

The French bean harvest was performed once, when about $75 \%$ of the pods on the plant were in the phase of technological maturity, which fell from the third ten days of July to the first ten days of September (Tab. 2). The number and yield of pods were determined from the plot: total, marketable and non-marketable, small pods, undersized, unshapely and overripe pods, as well as those with symptoms of disease. The study results were statistically elaborated by means of variance analysis and the Tukey confidence intervals at a significance level of $\mathrm{p}=0.05$.

Table 1. Soil analysis results (on average from two soil samples) in study years

\begin{tabular}{lcccccccc}
\hline \multirow{2}{*}{ Forecrop } & Year & $\mathrm{pH}_{\mathrm{H} 2 \mathrm{O}}$ & $\begin{array}{c}\text { Salinity } \\
\mathrm{g} \mathrm{NaCl}\end{array}$ & \multicolumn{4}{c}{$\begin{array}{c}\text { Macroelements } \\
\text { mg dm }\end{array}$} \\
\cline { 6 - 9 } soil
\end{tabular}

Table 2. Seed sowing and French bean harvest dates (for processing) in the study years 2003-2005

\begin{tabular}{|c|c|c|c|c|c|c|c|c|c|c|}
\hline \multirow[b]{2}{*}{ Sowing term } & \multicolumn{3}{|c|}{ Sowing date } & \multicolumn{3}{|c|}{ One-time pod harvest date } & \multicolumn{4}{|c|}{$\begin{array}{l}\text { Number of days } \\
\text { (sowing-harvest) }\end{array}$} \\
\hline & 2003 & 2004 & 2005 & 2003 & 2004 & 2005 & 2003 & 2004 & 2005 & Mean \\
\hline May (middle) & 14.05 . & 18.05. & 21.05. & $21-23.07$ & $4-7.08$ & 27.07.-2.08. & 69 & 80 & 72 & 74 \\
\hline May ( $3^{\text {rd }}$ ten days $)$ & 21.05 . & 26.05 . & 25.05 . & $21-29.07$ & $9-11.08$. & $2-5.08$ & 67 & 76 & 71 & 71 \\
\hline May/June & 28.05 . & 01.06. & 31.05. & 29-31.07. & 17-19.08. & $5-10.08$ & 63 & 78 & 70 & 70 \\
\hline June ( $1^{\text {st }}$ ten days $)$ & 04.06. & 08.06. & 07.06. & $6-13.08$ & $19-26.08$ & $10-17.08$ & 68 & 77 & 69 & 71 \\
\hline June (middle) & 12.06. & 15.06. & 13.06. & $12-20.08$ & $1-3.09$. & $17-26.08$ & 66 & 79 & 72 & 72 \\
\hline \multirow[t]{2}{*}{ June ( $3^{\text {rd }}$ ten days $)$} & 23.06. & 23.06. & 21.06. & $20-26.08$ & 6-8.09. & 31.08.-7.09. & 62 & 77 & 76 & 72 \\
\hline & & & & & & Mean & 66 & 78 & 72 & 72 \\
\hline
\end{tabular}




\section{RESULTS AND DISCUSSION}

Conducting French bean sowing in six assumed terms had slight divergences of a few days in the study years (Tab. 2), first of all due to different humidity conditions (Tab. 3) and the possibility of appropriate soil preparation. The difference between the earliest and the last French bean sowing term was 31 days in the year 2005, and 40 days in the year 2003 .

Study results demonstrated that the number of days from sowing to French bean pod harvest in the phase of technological maturity varied from 62 to 80 days, depending on the sowing date and study year (Tab. 2). Delaying the French bean sowing date resulted in the slight shortening of the plant vegetation period. However, larger differences in the length of French bean plant vegetation period resulted from different arrangement of meteorological factors in the study years (Tab. 3).

In the year 2004, when mean air temperature in the period from the second ten days of May to the second days of July was lower, as compared to the mean of 1951-2000, the French bean vegetation period was the longest and equalled 76-80 days, depending on the sowing date (Tabs 2 and 3). However, in the year 2003, with higher daily mean air temperature, as compared to the mean of 1951 -2000 in May (by $3.2^{\circ} \mathrm{C}$ ), June (by $0.9^{\circ} \mathrm{C}$ ) and July (by $1.9^{\circ} \mathrm{C}$ ), the plant vegetation period was the shortest and equalled 62-69 days, depending on the sowing date. The vegetation course of French bean plants in the study years was differentiated and depended upon environmental conditions. French bean plants revealed the highest variability as to the starting date of blooming, length of blooming phase and the length of the period from the beginning of pod setting to the harvest, which was presented in a study by Łabuda and Brodaczewska (2007 b), on the biology of flowering of plants from the examined sowing dates. The researchers' studies reveal that the beginning of French bean plant flowering from the first two growing terms in 2004 fell after 42-43 days after emergence, and much faster in the year 2003, i.e. after 30-32 days after emergence.

The total pod yield and marketable yield of French beans, with the application of a one-time pod harvest, was significantly variable depending on the sowing date, study year and cultivar features (Tabs 4 and 5). On the basis of the results from three study years, the highest total pod yield and marketable French bean pod yield under field growing conditions was obtained from the sowing date that had fallen on the first ten days of June, which was 15.45 and $11.06 \mathrm{t} \mathrm{ha}^{-1}$, respectively, whereas the lowest total mean pod yield and marketable yield was obtained from the first sowing date, which fell upon the middle of May and was 12.54 and $9.54 \mathrm{t} \mathrm{ha}^{-1}$, respectively. A similar and insignificantly different pod yield was obtained from the last sowing date at the end of June. On average from the three years of the study, six growing terms and four cultivars, the total pod yield and French bean marketable pod yield with the application of a one-time harvest was 14.14 and

Table 3. Mean air temperature and total rainfall in 2003-2005 (experimental field Felin-Lublin)

\begin{tabular}{|c|c|c|c|c|c|c|c|c|c|}
\hline \multirow{2}{*}{ Month } & \multirow{2}{*}{ Ten-day periods } & \multicolumn{4}{|c|}{ Air temperature $(\mathrm{C})$} & \multicolumn{4}{|c|}{ Sum of rainfall $(\mathrm{mm})$} \\
\hline & & 2003 & 2004 & 2005 & $1951-2000$ & 2003 & 2004 & 2005 & $1951-2000$ \\
\hline \multirow{3}{*}{ May } & $\mathrm{I}$ & 16.5 & 13.6 & 10.8 & 11.6 & 8.9 & 10.1 & 32.8 & 16.6 \\
\hline & II & 14.3 & 10.8 & 10.5 & 13.6 & 40.6 & 11.3 & 65.0 & 18.3 \\
\hline & III & 17.8 & 11.4 & 18.0 & 13.7 & 21.9 & 16.6 & 0.2 & 23.5 \\
\hline \multirow{3}{*}{ June } & I & 19.1 & 15.7 & 13.4 & 16.0 & 2.6 & 3.7 & 47.1 & 20.8 \\
\hline & II & 17.0 & 15.8 & 17.2 & 16.3 & 15.3 & 25.9 & 7.4 & 21.2 \\
\hline & III & 16.1 & 16.1 & 17.4 & 17.1 & 21.7 & 20.3 & 1.4 & 23.8 \\
\hline \multirow{3}{*}{ July } & I & 17.5 & 17.1 & 18.9 & 17.4 & 24.9 & 4.7 & 0.0 & 23.5 \\
\hline & II & 19.4 & 17.3 & 19.9 & 18.2 & 43.7 & 27.5 & 22.4 & 25.7 \\
\hline & III & 22.4 & 20.0 & 20.4 & 18.0 & 29.5 & 58.3 & 87.4 & 29.0 \\
\hline \multirow{3}{*}{ August } & $\mathrm{I}$ & 20.1 & 19.0 & 16.5 & 18.5 & 0.7 & 14.7 & 103.9 & 23.8 \\
\hline & II & 19.2 & 19.2 & 16.4 & 17.4 & 6.7 & 9.1 & 3.2 & 27.0 \\
\hline & III & 17.5 & 17.0 & 17.8 & 15.9 & 19.6 & 24.7 & 1.6 & 19.3 \\
\hline \multirow{3}{*}{ September } & I & 12.3 & 14.0 & 16.8 & 14.8 & 2.7 & 1.2 & 0.0 & 19.1 \\
\hline & II & 13.9 & 14.3 & 14.4 & 12.6 & 14.1 & 0.4 & 8.9 & 18.3 \\
\hline & III & 14.2 & 10.4 & 13.5 & 11.1 & 12.2 & 12.6 & 9.1 & 14.8 \\
\hline
\end{tabular}




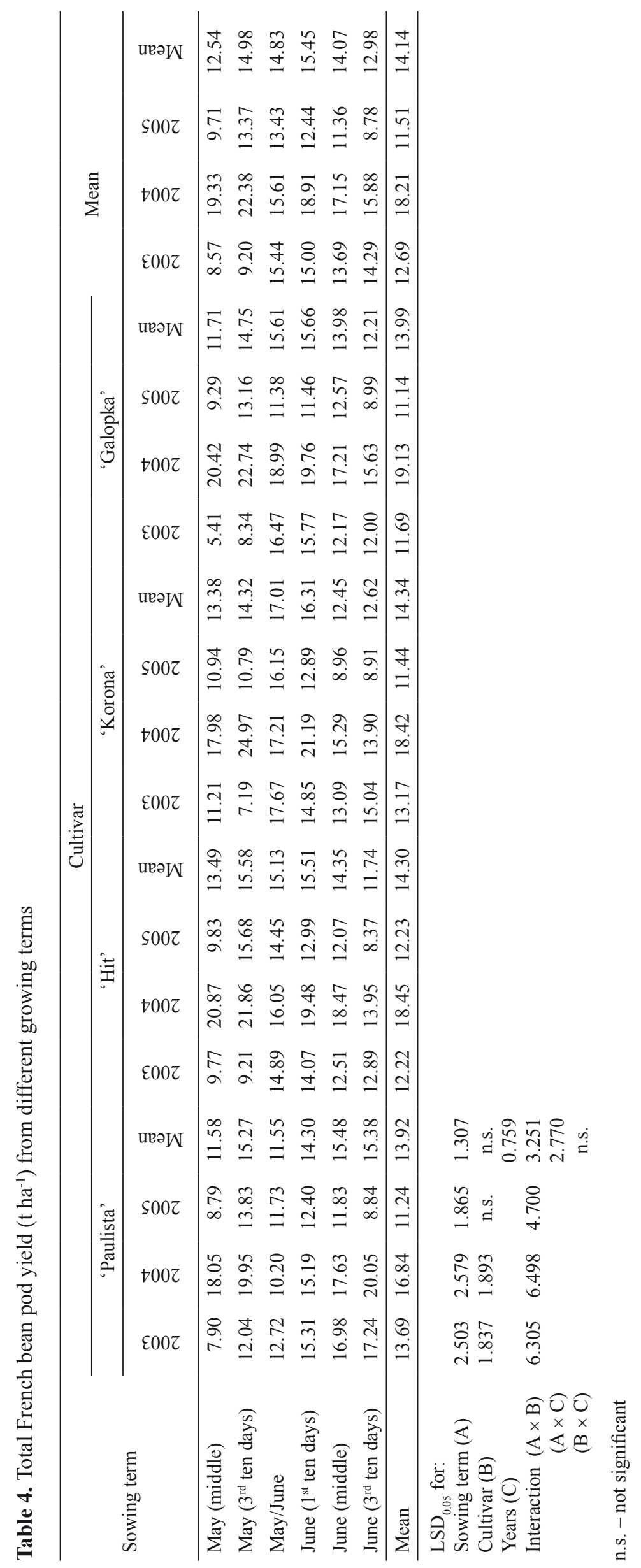




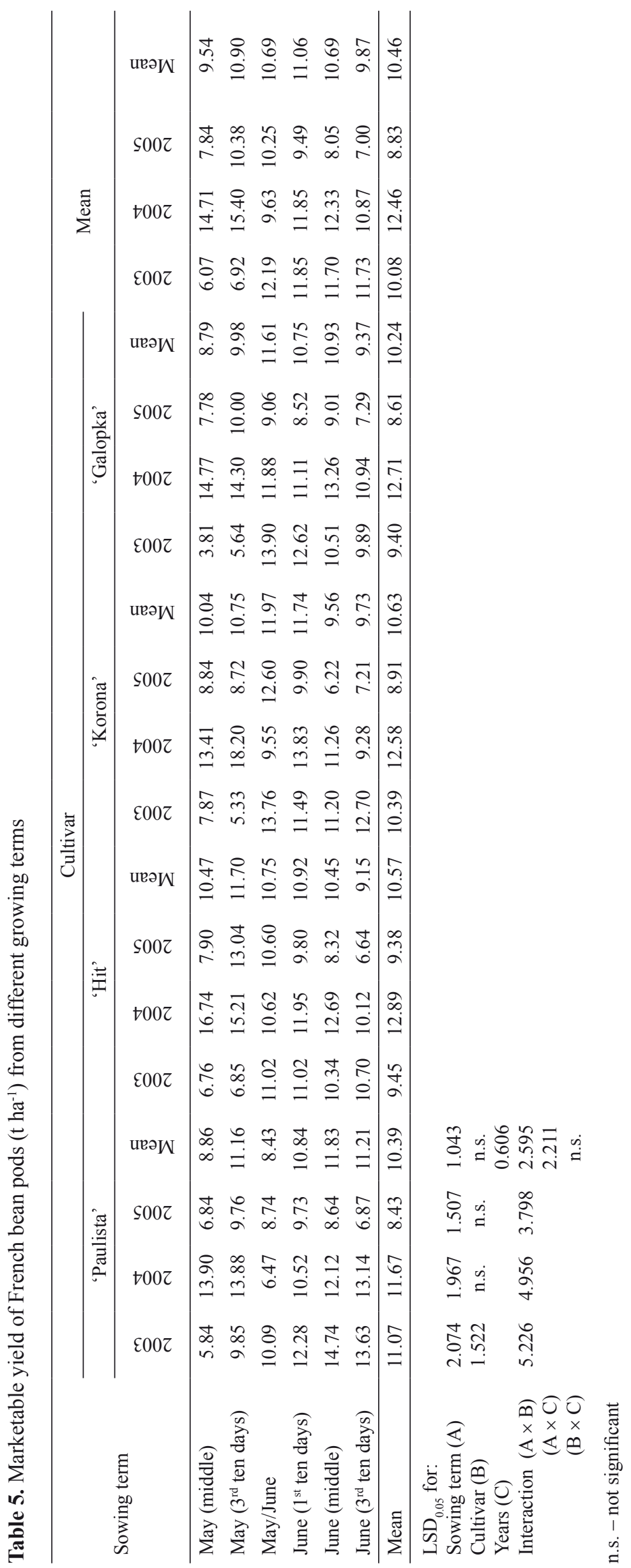


$10.46 \mathrm{t} \mathrm{ha}^{-1}$, respectively. Significant differences occurred in the French bean yield quantity in particular study years. In 2004, when the longest plant vegetation period was reported, the highest French bean pod yield was obtained in all of the growing terms. On average it amounted to 18.21 $\mathrm{t} \mathrm{ha}^{-1}$ (total pod yield), whereas the marketable pod yield was $12.46 \mathrm{tha}^{-1}$. At the same time, the share of marketable pod yield in the total yield was low and amounted only to $68.4 \%$ in 2004 . In the weather course conditions of 2004, when an uneven pace of growth and pod formation was observed, the highest share of non-marketable pods in the total yield was demonstrated (on average $31.6 \%$ ), which was mainly constituted by unshapely and overripe pods. However, in the years 2003 and 2005, the share of marketable pod yield in the total yield was higher and amounted to 79.4 and $76.7 \%$, respectively. The share of marketable French bean pod yield in the total yield slightly varied, depending on the sowing term, and it ranged from 72 to $76 \%$ on average from the years and cultivars (Fig. 1). The lowest

\section{Sowing term}
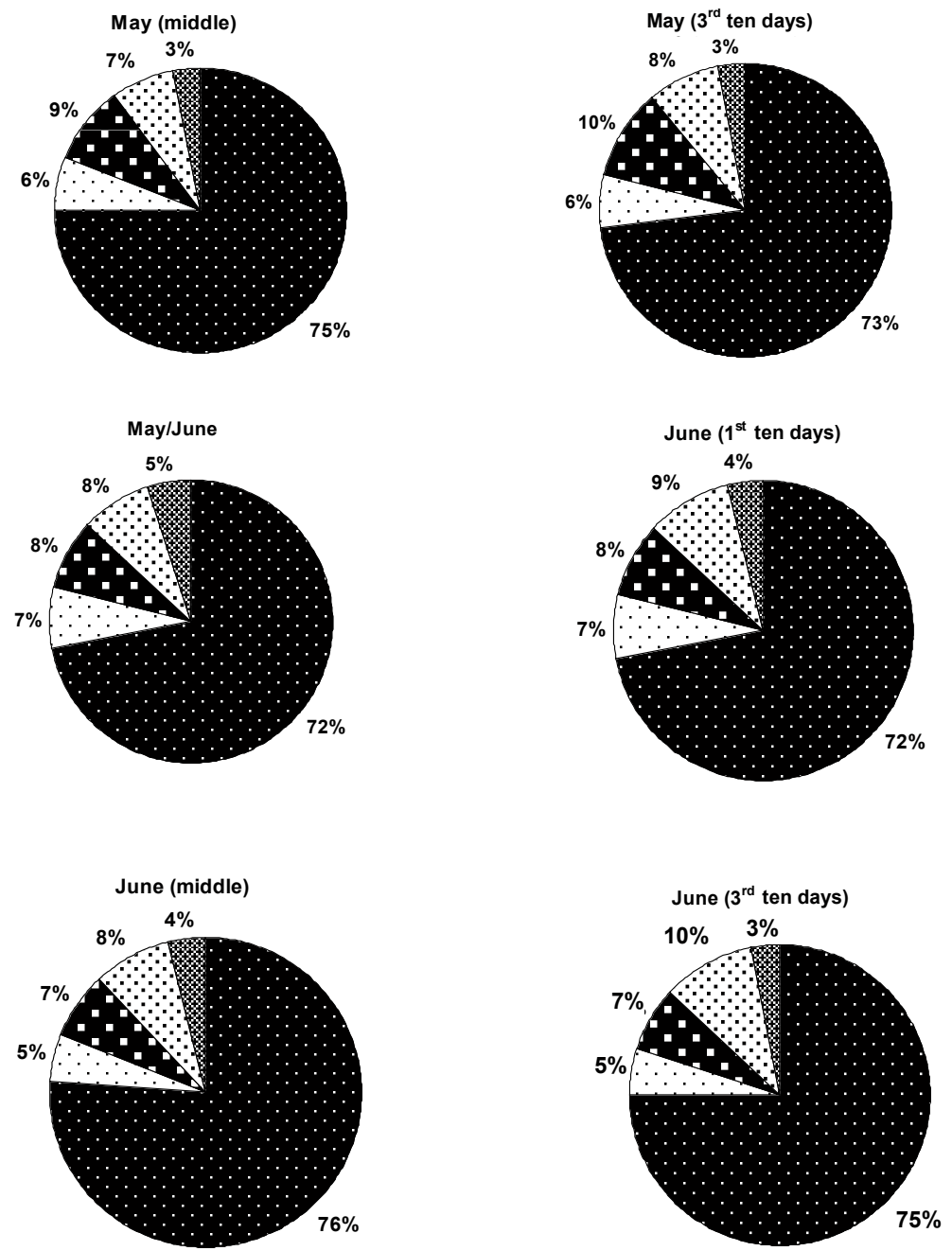

Marketable yield

Small pods

Unshapely pods

Overripe pods

Pods with disease symptoms

Figure 1. Share of marketable yield and non-marketable yield fraction in the total yield, determined by the French bean sowing term (mean from cultivars and years) 
share of marketable yield in the total yield ( $72 \%)$ was obtained in the French bean yield from May/ June sowing and from the first ten days of June. At the same time we demonstrated that of the total pod yield from these growing terms, the highest was the share of small, undersized pods (7\%). In addition, we found that the undersized pods constituted 52 $-53 \%$ of the total number of non-marketable pods on a plant (Fig. 2).

On the basis of comparing the yielding of four French bean cultivars - 'Paulista', 'Hit', 'Korona' and 'Galopka' - from six growing terms, with the application of a one-time pod harvest, it can be concluded that a satisfactory mean marketable pod yield from the three years of the study was obtained from sowing in the period from the third ten days of May to the middle of June (Tab. 5). Study results (Labuda and Brodaczewska 2008) demonstrated that the quality of marketable French bean pods obtained from all six sowing dates was also satisfactory. However, the French bean pods obtained from plants sown in June and whose maturity was in August and the beginning of September had the highest content of both dry matter and total chlorophyll.
In studies with sweet corn, the application of a few growing terms (from 20 April to 15 June), in order to prolong the harvest period, demonstrated that the highest corn cob yields of best quality were obtained from sowing in the period from 20 April to 4 May. It was demonstrated that the weather course in these years affected the yield and qualitative features of cobs from different sowing terms to the greatest extent. Delaying the sweet corn sowing term caused a gradual shortening of the vegetation period in warm and moderately dry, or dry years, whereas in lower temperature conditions and precipitation in the phase of generative development, a prolongation of the plant vegetation period was observed (Waligóra and Kruczek 2003). In the studies described in this article, the French bean vegetation period (of the latest sowing term at the end of June) was shortened in 2003 to 62 days during growing conditions with a higher air temperature than the average air temperature in this region, whereas it was prolonged to 76 days in the year 2005, when water deficiency in the period from mid-June to mid-July distinctly limited the plant growth pace (Tabs 2 and 3).

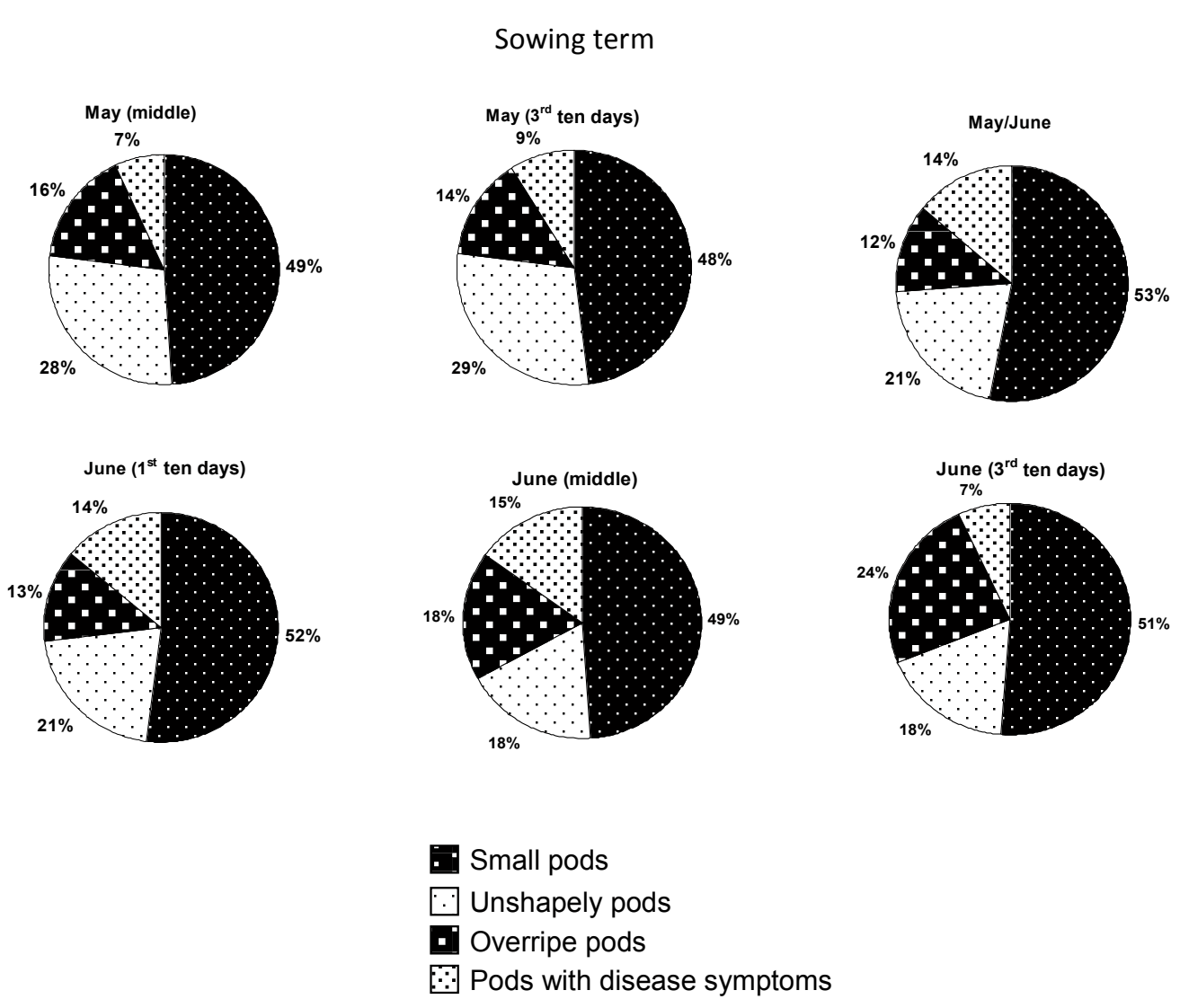

Figure 2. Structure of non-marketable pod number on a French bean plant, determined by sowing term (mean from cultivars and years) 
French bean is a plant characterised by a yielding variability in particular years, due to a differentiated course of atmospheric conditions; this mainly concerns total precipitation and rainfall distribution, as well as air temperature. The plants demonstrated the highest sensitivity to water deficiency in July, so irrigation is justifiable in this period (Rolbiecki and Rzekanowski 1996, Rolbiecki et al. 2003).

The studies contained in this paper demonstrated that the total French bean pod yield varied from $5.41 \mathrm{tha}^{-1}$ in the 'Galopka' yellow pod cultivar from mid-May sowing in the year 2003 to $24.97 \mathrm{tha}^{-1}$ in the 'Korona' yellow pod cultivar, sown in the third ten days of May 2004 (Tab. 4).

The obtained results confirm the reports of other researchers on the high variability of yieldcreating features, including the number of pods set on a plant, the environmental factors and cultivar features (Beaver et al. 1994, Mouhouche et al. 1998, Ferreira et al. 2000, Sağlam et al. 2000, Sękara and Poniedziałek 2001).

Studies conducted in Croatia (Borosic et al. 2000) revealed that in growing French beans for processing from sowing in the third ten days of June and in mid-July, the prolongation of the yielding period was extended to mid-October. Pod yield, with the application of necessary watering (in this growing period) was 9.5-14.0 $\mathrm{t} \mathrm{ha}^{-1}$ depending on the years, and the number of pods per plant varied from 4.3 to 11.5 (Borosic et al. 2000).

Study results in other climatic conditions (Bangladesh) also confirmed the significant effect of the bean growing term upon the morphological and reproductive features of plants, as well as on yield quantity (Begum et al. 2003). The researchers' study results show that higher bean seed and pod yields were obtained from a January sowing, compared to the February growing term. Labuda and Brodaczewska (2007 b) demonstrated that in French bean grown from different sowing dates, the total pod number per plant was between 19.8 it. (from mid-May sowing) and 26.7 it. (from late May and early June sowing).

\section{CONCLUSIONS}

1. The application of several French bean sowing dates, from the middle of May to the end of June in one-week intervals, significantly affected the quantity and structure of pod yield and the yielding period. The highest total and marketable pod yield, 15.45 and $11.06 \mathrm{t} \mathrm{ha}^{-1}$, respectively, was obtained from plants sown in the first ten days of June, whereas the lowest, 12.54 and $9.54 \mathrm{t} \mathrm{ha}^{-1}$, respectively, was from those sown in the middle of May.

2. As a result of performing a one-time French bean pod harvest, the share of non-marketable pod yield in the total yield was on a similar level (24-28\%), depending on the growing term. Variability was demonstrated in the share of particular non-marketable yield fractions, depending on the sowing date. The highest share (9-10\%) in total pod yield, obtained from the terms in the middle and third ten days of May, was constituted by unshapely pods, whereas small, undersized pods were obtained $(7 \%)$ from the sowing in May/June and the first week of June, and overripe pods (10\%) from the end of June sowing.

3. Growing four French bean cultivars from sowing in the period from the middle of May to the end of June allowed for an extension in the period of fresh pod harvest to six or seven weeks. French bean pod harvest started in the third ten days of July and lasted until the first ten days of September.

\section{REFERENCES}

AnONYMous, 2002. UNECE Standard for beans (FFV-06) Economic and Social Council. TRADE/WP.7/2001/9/ Add.1, 10 January 2002.

BĄKowski J., 2002. Przydatność i jakość warzyw dla zamrażalnictwa. Przem. Spoż. 6: 8-11.

Beaver J.S., Roman-Hernandez O., 1994. Green-shell bean production in Puerto Rico at different planting dates. J. Agric. Univ. Puerto Rico. 78: 331-336.

Begum A., Ahad A., Kaisar M.O., Islam M.M., Anam M.K., 2003. Effect of sowing dates and fertilizer treatments on the reproductive variability of French bean (Phaseolus vulgaris). Pakistan J. Biological Sci. 6(22): 1897-1901.

Borosic J., Romic D., Dolanjski D., 2000. Growth and yield components of dwarf French bean grown under irrigation conditions. Acta Hort. 533: 451-459.

Elkner K., Nowakowska T., 2000. Polskie odmiany fasoli szparagowej dla zamrażalnictwa. Przem. Ferment. Owoc. Warz. 2: 34-36.

Ferreira M.E., Ferreira A., Monteiro A.A., de Melo Abreu J.P., Bianco V.V., 2000. A simple weather driven model to determine harvest date of green beans for freezing using quantitative and qualitative criteria. Acta Hort. 533: 489-495.

Górska-Warsewicz H., 2003. Konsumenci żywności mrożonej. Przem. Spoż. 4: 14-15: 22.

Gross Y., Kigel J., 1994. Differential sensitivity to hight temperature of stages in the reproductive 
development of common bean (Phaseolus vulgaris L.). Field Crops. Res. 36: 201-212.

Kossowski M., Tendaj M., Łabuda H., 1978. Ocena przydatności karłowych odmian fasoli szparagowej do jednorazowego zbioru. Biul. Warz. XXI: 93-111.

Łabuda H., Baran A., Papliński R., 2006. Kwitnienie i zawiązywanie strąków siedmiu odmian fasoli szparagowej (Phaseolus vulgaris L.) w zróżnicowanych warunkach uprawy. Acta Agrobot. 59(1): 439-446.

Łabuda H., BrodaczewsKa A., 2007 a. Yield and quality characteristics of seven snap bean cultivars for early cropping. In: Spontaneous and induced variation for the genetic improvement of horticultural crops. P. Nowaczyk (ed.), University Press, University of Technology and Life Sciences in Bydgoszcz: 245-250.

Łabuda H., Brodaczewska A., 2007 b. The influence of environmental factors on flowering of French bean (Phaseolus vulgaris L.) Acta Agrobot. 60(2): 153-159.

Łabuda H., Brodaczewska A., 2008. Jakość strąków fasoli szparagowej w zależności od terminu siewu. Zesz. Probl. Post. Nauk Roln. 527: 185-191.

MilczyńsKa E., Lenartowicz K., 2007. Fasola zwykła karłowa. In: „Lista opisowa odmian. Rośliny warzywne. Strączkowe”. COBORU, Słupia Wielka.

Mounouche B., Ruget F., Delécolle R., 1998. Effects of water stress applied at different phenological phases on yield components of dwarf bean (Phaseolus vulgaris L.). Agronomie 18: 197-205.

Nosecka B., Bugata A., 2010. Polski handel zagraniczny mrożonymi warzywami i owocami. Przem. Ferment. Owoc. Warz. 2: 6-10.

Nosecka B., Mierwiński J., Smoleński T., Stępka G., Bugata A., StrojewsKa I., 2009. III. Warzywa. Rynek Owoc. Warz. 35: 23-43.

Plucińska M., Michalik H., Bąowski J., 1977. Przydatność odmian fasoli szparagowej dla przemysłu konserwowego i zamrażalnictwa. Biul. Warz. XX: 427-453.

RolBIECKI S., RZEKANowski C., 1996. Uwarunkowania meteorologiczne plonowania fasoli szparagowej na glebie piaszczystej w warunkach nawadniania. Zesz. Probl. Postęp. Nauk Rol. 438: 97-101.

Rolbiecki S., Rolbiecki R., Rzekanowski C., 2003. The effect of surface drip irrigation on yields of chosen vegetable crops cultivated in very light soil. Veg. Crops Res. Bull. 58: 69-75.

Sęrara A., Poniedzialek M., 2001. The effect of sowing terms upon the yield and course of phenological phases of fine-seed cultivar of faba bean (Vicia faba L. var. major Harz). Folia Hort. 13/1: 23-31.
SaĞlam N., GeboloĞlu N., Ece A., Fidan S., Yazgan A., 2000. Effects of different sowing dates on harvesting date and yield of beans under plastic tunnels. Acta Hort. 533: 315-321.

Waligóra H., KruczeK A., 2003. Wpływ terminu siewu na plonowanie dwóch odmian kukurydzy cukrowej. Fragm. Agron. 3(79): 27-39.

\section{TERMIN SIEWU JAKO CZYNNIK KSZTAETUJACCY PLONOWANIE FASOLI SZPARAGOWEJ DO PRZETWÓRSTWA}

Streszczenie: Badania polowe przeprowadzonow latach2003-2005 w Gospodarstwie Doświadczalnym UP w Lublinie. Fasolę czterech szparagowych odmian: 'Paulista' i 'Hit' (zielonostrąkowe), 'Korona' i 'Galopka' (żółtostrąkowe) uprawiano na glebie płowej wytworzonej z utworów lessowatych na marglach kredowych, zwierającej średnio $1,4 \%$ substancji organicznej. Nasiona wysiewano $\mathrm{w}$ sześciu terminach $\mathrm{w}$ okresie od połowy maja co 6-7 dni do końca czerwca. Zbiór fasoli szparagowej przeprowadzano jednorazowo, gdy około $75 \%$ strąków na roślinie było $\mathrm{w}$ fazie dojrzałości technologicznej, co przypadało od trzeciej dekady lipca do pierwszej dekady września. Określono z poletka i z rośliny liczbę i plon strąków: ogółem, handlowy i niehandlowy - strąki małe niewykształcone, niekształtne, przejrzałe i $\mathrm{z}$ objawami chorobowymi. Największy plon strąków ogółem i handlowy - średnio odpowiednio 15,45 i $11,06 \mathrm{t} \mathrm{ha}^{-1}$ uzyskano $\mathrm{z}$ roślin pochodzących $\mathrm{z}$ siewu $\mathrm{w}$ pierwszej dekadzie czerwca, natomiast najmniejszy $-12,54$ i 9,54 $\mathrm{t} \mathrm{ha}^{-1} \mathrm{z}$ siewu w połowie maja. W wyniku przeprowadzenia jednorazowego zbioru strąków fasoli szparagowej udział plonu niehandlowego strąków w plonie ogółem był na zbliżonym poziomie (24-28\%) w zależności od terminu uprawy. Wykazano zmienność udziału poszczególnych frakcji plonu niehandlowego (strąki niewykształcone, niekształtne, przejrzałe i z objawami chorobowymi) w zależności od terminu siewu. Uprawa czterech odmian fasoli szparagowej z siewu w okresie od połowy maja do końca czerwca pozwoliła na wydłużenie okresu zbiorów świeżych strąków do sześciu, siedmiu tygodni.

Received August 12, 2010; accepted November 8, 2011 